\title{
ISIS COMMUNICATION STRATEGY
}

Growing threats and worldwide influences of jihadist organizations such as the Islamic State of Iraq and Syria (ISIS) rely on ideological, military, financial and operational capacities. Abu Bakr al-Baghdadi, the leader of ISIS responded to insurgents' hopes and offered new concept of jihad and implementation of sharia regulations as well as establishment of the historic caliphate. Moreover, seizure of large parts of Syria and Iraq, support of Sunni communities and hostility against Shia population, as well as terror campaign and brutal executions reinforced the position of the organization and defined new forms of jihad compared to dignity, bravery, honor and adventure. So far, more than 30 different groups, including insurgents from Asia and Africa have taken an oath to al-Baghdadi al-Baghdadi (Feakin, Wilkinson, 2015: 7-8).

However, ISIS could not succeed without appropriate propaganda and communication strategies that enabled to recruit and inspire insurgents, including foreign volunteers. In fact, ISIS is the first organization, which exploits effectively propaganda and media tools like Internet websites, online journals or social medias and new communication technologies. Besides, propaganda techniques play a crucial role in motivation and agitation process that encourages young persons to join the battlefield in Syria and Iraq and to carry out terrorist attacks in the West. The series of terror acts that occurred in France in 2015 (Callimachi, Yardley, 2015) and the Brussels bombings in 2016 (Khomami, 2016).

ISIS communication strategy reflects the following channels:

- Liturgical speeches and classic Arabic rhetoric;

- Official media channels;

- Internet forums and social medias;

- Encrypted communication.

\section{LITURGICAL SPEECHES AND CLASSIC ARABIC RHETORIC}

The liturgical sermon called khutba in Arabic is one of the oldest narrative and oratory forms in the Arab and Muslim world. It is presented in mosques during Friday's prayer or on special occasions of feasts and holidays. Basic narration and stylistic features reflect two parts of the speech. The first one regards short prayers, religious invocations and citations of Quranic verses. It is always followed by the expression: wa ba' $d$ (and then; afterwards), which indicates separation between passages in the speech. The second part is delivered after a short break and it is the main fragment of the sermon. It usually concerns religious and moral values or social questions such as unemployment, drug abuse, organized crime or family crisis and positive values of Islam. Discussions are based on the 
Quran and hadiths (stories, statements and report attributed to the Prophet Mohammad) or various allegories and examples from history and everyday life. The speech is concluded by other religious citations (Jones, 2012: 195-232).

Moreover, the central fragment of the sermon also reflect implementation of rhetorical devices (balāgha in Arabic) regarding different forms of narration and compositions, appropriate words and arguments as well as rhetorical figures like comparisons, metaphors, repetitions or antithesis (Gaffney, 1994: 271-293).

Khutba also includes some non-verbal devices and speaker's attributes such as theological skills, respect among believers, presentation of the sermon in liturgical podium above the auditorium as well as sacral clothes during the speech or balanced voice and gestures (Jones, 2012: 195-232).

It should be pointed out that religious discourse was often politicized by Islamist groups, which used the structure of khutba or balāgha to present political messages in the second part of the speech. Traditional liturgical discourse has also affected Abu Bakr al-Baghdadi who applied the concept of the sermon in his official speeches. The sermon delivered in Ramadan 2014, in which he announced the establishment of the caliphate is a good example in that context (Strange, 2014). Contrary to previous jihadist leaders, al-Baghdadi respected all conventions and etiquettes regarding non-verbal and narration features of khutba (Jones, 2012: 195-232).

His sermon was presented in classic Arabic in the main mosque in Mosul above the auditorium in liturgical podium. Al-Baghdadi was wearing sacral clothes and he was standing up at the first step 67 of speech and then he was sitting down during other parts of the discourse. He also avoided loud voices, chaotic gestures or reactions and he used index fingers to precise or underlines some questions.

Apart from personal skills, al-Baghdadi followed strict narration and stylistic devices of khutba and balägha. He started his speech with religious invocations and citations and after a short break he refers to main subjects concerning spiritual values of the holy month, which absolves from all sins and rehabilitates human souls. Ramadan was confronted with specific concept of jihad described by al-Baghdadi as scarified efforts facilitating defeat of enemies and implementation of Islam values and the historic caliphate.

Furthermore, Al-Baghdadi's opinions were followed by appropriate argumentations based on sources such as the Quran, hadiths or citations of noble personalities from the history of Muslim empires. For examples, he refers to the speech of the Caliph Abu Bakr who became the first Muslim Caliph from 632 to 634 following the Prophet Muhammad's death. Al-Baghdadi appeals to the famous speech of Abu Bakr after seizure of power: "I have been given the authority over you, and I am not the best of you. If I do well, help me; and if I do wrong, set me right. Sincere regard for truth is loyalty and disregard for truth is treachery. The weak amongst you shall be strong with me until I have secured his rights, if God will; and the strong amongst you shall be weak with me until I have wrested from him the rights of others, if God will. Obey me so long as I obey God and His Messenger. But if I disobey God and His Messenger, ye owe me no obedience. Arise for your prayer, God have mercy upon you" (Munir, 2005: 39-40).

Al-Baghdadi avoided straight political messages but the appeal to the symbolic speech of Abu Bakr enabled to authorize the new Caliphate and to justify ISIS policy 
regarding violent implementation of sharia laws, executions of hostages and religious minorities. It should be pointed out that al-Baghdadi's speech was addressed to local audiences that have been used to traditional and liturgical discourse. Furthermore, the religious features strengthened ISIS political messages and they stimulated allegiance of rival jihadist groups and recruitment of new insurgents.

\section{OFFICIAL MEDIA CHANNELS}

ISIS has implemented some innovative forms of propaganda that includes new technologies such as TV channels, radio stations or sophisticated online magazines issued in PDF versions. It should be pointed out that all sources are available in different free Web hosting or uploading sites. They are released in multilingual versions in order to attract wide audience, especially young militants from Western countries (Daninos, 2015: 10-14).

Dabiq magazine became an important communication platform for radical Islamists around the world (Jihadology, 2015). The name refers to the historic Battle of Marj Dabiq near Aleppo in Syria. In 1516 the Ottoman army conquered most of the Middle East, which encompassed the entire region of Syria and built the new Empire (Gray, 1975: 14-15).

Instead of long theological and political discussions, the magazine contains short messages based on suggestive graphics and provocative pictures similar to tabloid press or comics. Cover and first pages from the magazine usually present main headlines, including slogans regarding policy and strategy of the new caliphate. Statements, manifestos and short reports are always followed by photos illustrating ISIS successful offensives and campaigns in Syria and Iraq, images of wounded soldiers among fires and explosions as well as victorious parades of militants in controlled cities or harvest campaign and distribution of food and water. Other pictures show brutal executions of Shia prisoners, representatives of Christian and Yazidi communities or some colorful and sophisticated graphics showing spectacular terrorist attacks around the world. The pictures are followed by symbolic sentences such as: "Khalifa declared", "A new era has arrived" or: "It's either the Islamic state of the flood" (Jihadology, 2015).

The Dabiq respects traditional concept of propaganda popularized by previous jihadist leaders such as Osama bin Laden, Abu Musab al-Zarqawi. For example, different opponents are usually called şalïbiyyün (crusaders), taghut (a devil, a Satan) or kuffār (sinners) and murtaddūn (apostates). The meanings are already known for radical Islamists, who compare Western and local authorities to the Devil, sins, immorality, crusaders wars or Zionism. Furthermore, the Dabiq presents transliterations of the Arabic words without English equivalents in order to conserve stylistic traditions of jihadist propaganda and to identify symbolic meanings that unite and strengthen ISIS insurgents and followers. It should be also pointed out, that ISIS hijacked the stylistic and linguistic concept of the Inspire magazine issued by Anwar al-Awlaqi who has been killed in 2011 by drone attack on his convoy in Jawf province, Yemen (Koplowitz, 2013). Sophisticated and modern style of the Inspire magazine contained short messages in English based on suggestive graphics and significant pictures similar to tabloid press or comics and graffiti. The slogans exposed in the journals usually refer to martyrdom and bravery of militants as well as destructive activities of Western countries. 
Apart from online journals and magazines ISIS broadcasts the radio station called al-Bayan (Statement) and TV station al-Hayat Media Center as well as the Internet service Amaq Ikhbariyya (Depth of Information). The audiovisual tools enable to implement sophisticated programs and headlines, including high quality pictures, graphics and videos regarding statements on terrorist attacks, short multilingual reports from battlefields in Syria and Iraq, brutal executions of hostages as well as manifestos glorifying attacks against enemies and implementation of ISIS laws and regulation in controlled territories (Ajroudi, 2015).

For example, some media sources present modifications of heroes and graphics appearing in popular video games or Hollywood films. They are attributed to local fighters who are compared in that way to brave and famous heroes fighting with brutal enemies.

ISIS official media channels also include statements, which are often similar to war reports. They usually contain dates and type of attacks as well as number of casualties among security forces and civilians. However, descriptions and updates are always followed by appropriate graphics, pictures, color scheme and logotype that identify the organization.

\section{INTERNET FORUMS AND SOCIAL MEDIA}

Internet forums and social medias became a popular form of communication among ISIS militants, sympathizers or neutral Internet users interested in current events in the Arab-Muslim world. Besides, those devices create an alternative for formal statements and they facilitate informal communication, that includes short commentaries, sophisticated pictures and videos or sublime religious chants (Rudner, 2016: 8-25).

Moreover, social medias play and important role during terrorist attacks. Particular terrorist plot generates various posts and tweets that intensify fears, suspicions and information chaos among audiences and authorities. Internet messages include unconfirmed threats, exaggerated data and descriptions. In this regard, it is hard to manage and to separate true or false messages. It is also difficult to identify whether particular message is posted by jihadist militants, sympathizers of jihadism or neutral Internet users. This type of communication is often applied before official statements delivered after terrorist attacks.

ISIS also exploits Twitter networks instead of Facebook or Instagram profiles because in their opinions they have poor security and encrypting tools. ISIS Twitter profiles contain appropriate avatars and materials that demonstrate jihadist objectives. Every tweet generates other posts and profiles reflecting common ideas regarding glorification of ISIS fighters and condemnation of local and Western authorities or threats of future attacks (ibidem).

Furthermore, ISIS militants can freely express their opinions, manifestos, graphics and videos. The new phenomenon was obvious during the terrorist attack against the Charlie Hebdo magazine in Paris in January 2015. ISIS followers published a tragic photo of a dead policemen lying on the ground. It referred to first headlines from the attack showing a terrorist shooting a police officer who tried to help people executed in the editorial board of the Charlie Hebdo. Twitter accounts used by ISIS released the picture of the killed policeman with short inscriptions: "If we do not revenge the Prophet, we do not will know prosperity" and: "The attack against the newspaper which pub- 
lished pictures insulting the Prophet" (Twitter, 2015). The commentaries explained and justified the attacks and they glorified ISIS strategy against Western countries supporting antiterrorist coalition in the Middle East.

The violent response to the caricatures of the Prophet Mohammad published by the magazine has created an useful religious background for al-Baghdadi's organization, which tried to provoke French forces and engage them in Syria. Indeed, after the terrorist attacks in January and November 2015, France started airstrikes in Syria (Irish, Vidalon, 2015). It should be also noted that the tragic image of the policemen and the inscriptions affected other, similar tweets that emphasized the sense of revenge and victory over the enemy.

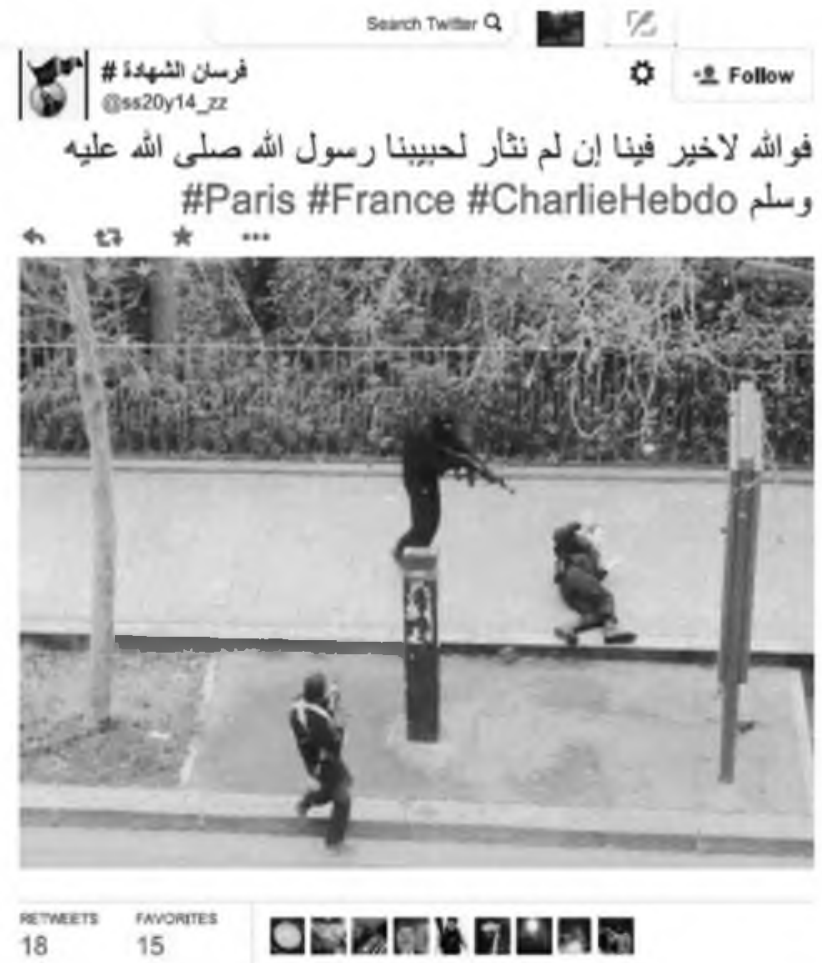

Picture 1. The example of the Tweet regarding the attacks against the Charlie Hebdo magazine

Source: Twitter (2015), http:/www.twitter.com/ss20y4 zz/status/ 5529008774030454784 (14.05.2016).

According to the United States Department of Defense there are around 6,000 active ISIS users. Some surveys estimate 46,000 ISIS supporters who use Twitter accounts (Astorino-Courtois, Canna, 2015: 11-13). It is also more and more difficult to identify potential supporters, militants and terrorists because they use various avatars, profiles, symbols and particular words that unite them and facilitate communication and exchange of materials. Moreover, blocking of Twitter accounts are ineffective because suspended profiles are replaced by new users who often change their avatars, profiles and settings of the account. 
It should be pointed out that jihadist communication in Twitter relies on appropriate Arabic words and phrases applied as hashtags. They usually refer to the following items: khilāfa (caliphate) and dawla islämiyya (Islamic State), jund al-khiläfa (soldiers of the caliphate) or they are derivated from the popular jihadist websites such as amaq ikhbariyya, shabakat al-jihäd al-alamiyyi (worldwide jihadi network) and anz̧ār al-mujahidūn (followers of mujahedeen) ${ }^{1}$. The examples are often modified and they include additional epithets in Arabic in case of blocking and suspension of the websites. However, the derivations enable to find and to renew the communication in blocked Internet services.

Many Tweets include different statements, threats and short commentaries posted after particular terrorist attacks. The accounts are usually attributed to the hashtag ghazwa mubāraka (blessed invasion) with an appropriate name of the country affected by terrorist threats and attacks. Some hashtags refer to well-known names of opponents like crusaders, sinners and apostates. The meanings refer to heroic Muslim conquests and victories during first ages of Islamic empires as well as during crusaders' wars. Emotional and pathetic connotations of the meaning identify common ideas and objectives among radicals who justify and glorify in that way terrorist attacks (Vidino, Hughes, 2015).

It should be pointed out that the communication in social medias also include code-switching, which concerns mixture of Arabic and English words and phrases as well as formal transcription of ISO (International Organization for Standard) or informal transcriptions of Arabic based on freestyle graphic equivalents. The concept is very popular in Internet mobile communications, especially among young Muslim generations. Internet users avoid translations of Arabic meanings in order to conserve symbolic character of words and their original semantic fields unavailable in Indo-European languages. However, conversation partners can't write or type classic Arabic or they do know how to transcribe correctly the words.

Umm Jihad ezumanularinah i Sh

Alhamdulillahi rabbil alimeen, I'm the most content I have ever been in my life $\mathrm{O}$

\& $235 \quad \star 14 \quad \cdots$

FIG. 8 Muthana on life in the caliphate, January 2015

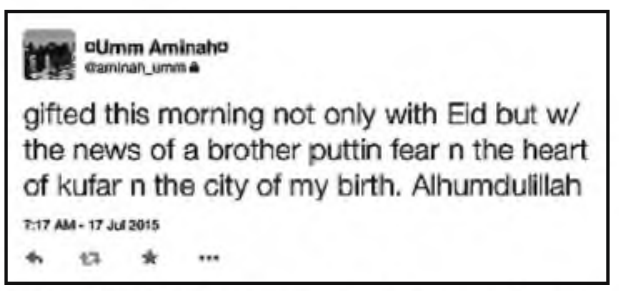

FIG. 23 Ariel Bradley celebrates the Chattanooga shootings.

Picture 2. The Examples of Arabic-English code-switching applied by jihadist in the Internet messengers

Source: L. Vidino, S. Hughes (2015), ISIS in America: from Retweets to Raqqa. The Program on Extremism, Washington, p. 9-10.

1 The following examples refer to various profiles and accounts created in Twitter service by ISIS members or sympathizers of the organization. Many accounts do not exist anymore but they are all available in my provide archives and they collected in PDF or Screenshots. 


\section{ENCRYPTED COMMUNICATION}

Recently, jihadists have applied advanced computer technologies such as hacking tools, mobile phone devices and encrypting programs, which facilitate protection of identity and conversations (Zetter, 2015).

For instance, in January 2016 ISIS hacked the TV station Bein HD 4 in order to spread its programs across the region (Webb, 2016). Bein HD 4 is a popular Arabic sport channel broadcasted by the Egyptian satellite provider Nilesat. The hacked station launched headlines about airstrikes, weather reports, lectures concerning jihadism and other propaganda materials that criticized al-Assad regime and glorified ISIS fighters.

ISIS also exploits vehicle communication and hidden codes. For example, in January 2016 British authorities foiled ISIS terror plot in the UK after intercepting suspicious chatter between commercial airline pilots. The two pilots, who were leaving Amsterdam's airport for the Middle Eastern, used coded language which made reference to pop music. They also used the emergency 'Mayday' frequency to discuss their terrorist plans (Robson, 2016).

The application of new technologies is also evident in the case of Telegram Messenger. ISIS encourages its followers to start using that popular Internet application in order to avoid surveillance. The Telegram has more than 50 million users, who send 1 billion messages a day. It also guarantees privacy and encrypted audiovisual conversations based on various communication channels (Smith, 2015).

Jihadists join the channels Akhbār al-Khiläfa (Caliphate Information), Akhbār al-Jihād (Jihad Information), Isdārāt al-Khilâfa (Publications of the Caliphate) or Nuqta I'lāmiyya li-al-Dawla al-Islāmiyya (Media Hotspot of the Islamic State) and Shajarat al-Khiläfa (the Tree of the Caliphate). Each channel include thousands of member who transfer and share messages, pictures and videos or they follow online chats with other Telegram users. Apart from ideological and propaganda materials, the Telegram enables to share operational, logistic and financial updates and details concerning ISIS activities, including preparation of terrorist attacks. The exchange of nearly 2000 photos, 14 voice message and 816 links demonstrate the growing influences of the application (Khan, 2015).

$$
* * *
$$

The research presented in the paper has demonstrated some innovative communication and propaganda techniques implemented by ISIS. Analysis of propaganda techniques showed that all communication channels affected different audiences. For instance, speeches delivered in Arabic by ISIS leader, Abu Bakr al-Baghdadi targeted local populations and stimulated their emotions, opinions and reactions thanks to liturgical style and implementation of non-verbal regulations of the sermon and traditional rhetorical devices.

Moreover, the agitation process reflected official websites, manifestos, online journals and statements released in various languages. ISIS leaders exploited the official communication channels to claim their responsibility for particular terrorist attacks and to present detailed information about damages and causalities. Besides, the official 
channels concerned appropriate style and narration as well as common graphics, colors and logotypes.

However, ISIS has also used social medias, which targeted Western audiences. Various Internet accounts and Tweeter profiles enabled to express different propaganda materials such as ideological posts, high quality video films, sophisticated pictures and graphics that glorify jihadism and threat or condemn political opponents. The materials spread extremist ideas among internet users, recruited new fighters and inspired terrorist attacks.

The research presented in the paper also showed some new challenges for counterterrorism and cybersecurity policies in the world. It should be pointed out that it is more and more difficult to identify potential supporters, militants and terrorists because they use various avatars, profiles, symbols and particular Arabic hashtags that unite them and facilitate communication and exchange of materials. Besides, blocking of Twitter accounts are ineffective because suspended profiles are replaced by new users who often change their avatars and profiles. Furthermore, implementation of advanced computer technologies, hacking tools or encrypting programs facilitate protection of identity and conversations and create additional risks for worldwide security.

\section{BIBLIOGRAPHY}

Ajroudi A. (2015), It sounds like BBC: ISIS seeks legitimacy via caliphate radio service, "Al-Arabiya News", 12.06.2015, http://english.alarabiya.net/en/media/television-and-radio/2015/06/12/ -It-sounds-like-BBC-ISIS-seeks-legitimacy-via-caliphate-radio-service-.html (10.11.2015).

Astorino-Courtois A., Canna S. et all. (2015), ISIL Influence and Resolve, "Special Operations Command Central - SOCCENT, A Strategic Multi-Layer (SMA) Periodic Publication", September 2015 .

Callimachi R., Yardley J. (2015), From Amateur to Ruthless Jihadist in France, "The New York Times", 17.01.2015, http://www.nytimes.com/2015/01/18/world/europe/paris-terrorismbrothers-said-cherif-kouachi-charlie-hebdo.html (10.11.2015).

Daninos F. (2015), Internet, arme de persuasion massive, "Hors-Serie science et avenir", Juillet-Aout 2015.

Feakin T., Wilkinson B. (2015), The future of jihad What next for ISIL and al-Qaeda?, "Strategic Insight, Australian Strategic Policy Institute", June 2015.

Gray R. (1975), The Cambridge history of Africa, Vol. 4, Cambridge.

Hannah Strange H. (2014), Islamic State leader Abu Bakr al-Baghdadi addresses Muslims in Mosul, "The Telegraph", 5.07.2014, http:/www.telegraph.co.uk/news/worldnews/middleeast/iraq/ 10948480/Islamic-State-leader-Abu-Bakr-al-Baghdadi-addresses-Muslims-in-Mosul.html (09.11.2015).

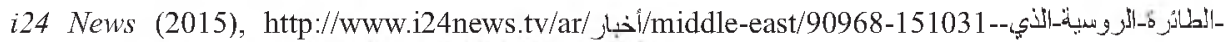

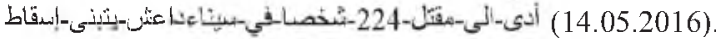

Irish J., Vidalon D. (2015), France launches air strikes against Islamic State in Syria, "Reuters", 27.09.2015, http://www.reuters.com/article/us-mideast-crisis-france-syria-idUSKCN0RR07 Y20150927\#eReZqrtooLY13th4.97 (14.05.2016).

Jihadology (2015), http://jihadology.net/category/dabiq-magazine/ (9.11.2015). 
Khan V., Watts B. et al. (2015), Massive Migration to Telegram, the new Jihadist Destination, "TRAC Insight", 30.10.2015, http://www.trackingterrorism.org/chatter/trac-insight-massive-migration-telegram-new-jihadist-destination (14.05.2016).

Khomami N. (2016), Brussels explosions: what we know so far, "The Guardian", 22.03.2016, http://www.theguardian.com/world/2016/mar/22/brussels-attacks-what-we-know-so-far (14.05.2016).

Koplowitz H. (2013), US Formally Admits Killing Anwar Al-Awlaki, 3 Other Citizens, In Drone Strikes, "International Business Times", 22.05.2013, http://www.ibtimes.com/us-formallyadmits-killing-anwar-al-awlaki-3-other-citizens-drone-strikes-full-text-1275805 (29.06.2014).

Linda Jones L. (2012), The Power of oratory in the medieval Muslim world, Cambridge.

Munir R. (2005), Al-Khitâba 'ind al-'arab, Bayrūt.

Patrick Gaffney P. (1994), The Prophet's pulpit, Berkeley.

Robson S. (2016), RAF foiled ISIS airline terror plot to bomb four UK cities after cracking pop song code, "The Mirror", 24.01.2016, http://www.mirror.co.uk/news/uk-news/raf-foiled-isis-airline-terror-7236025 (14.05.2016).

Rudner M. (2016), Electronic Jihad: The Internet as Al-Qaeda's Catalyst for Global Terror, w: Violent Extremism Online New Perspectives on Terrorism and the Internet, (eds.) A. Aly, S. Macdonald et all., London.

Smith D. (2015), ISIS is encouraging followers to download this popular messaging app, "Tech Insider”, 18.11.2015, http://www.techinsider.io/isis-to-followers-download-telegram-2015-11 (14.05.2016).

Strange H. (2014), Islamic State leader Abu Bakr al-Baghdadi addresses Muslims in Mosul, "The Telegraph", 5.07.2014, http:/www.telegraph.co.uk/news/worldnews/middleeast/iraq/ 10948480/Islamic-State-leader-Abu-Bakr-al-Baghdadi-addresses-Muslims-in-Mosul.html (09.11.2015).

Twitter (2015), www.twitter.com/ss20y4_zz/status/5529008774030454784 (20.01.2015).

Vidino L., Hughes S. (2015), ISIS in America: from Retweets to Raqqa, "The Program on Extremism", Washington.

Webb S. (2016), ISIS launch their own TV channel complete with its own weather reports, "The Mirror", 25.01.2016, http://www.mirror.co.uk/news/world-news/isis-launch-tv-channel-complete-7239984 (14.05.2016).

Zetter K. (2015), ISIS's Opsec manual reveals how it handles cybersecurity, "Wired", November, 19.11.2015, http://www.wired.com/2015/11/isis-opsec-encryption-manuals-reveal-terroristgroup-security-protocols/ (19.11.2015).

\begin{abstract}
The present paper concerns studies on innovative communication and propaganda strategies of the main jihadist group called "the Islamic State of Iraq and Syria" (ISIS). In fact, media and Internet agitations enabled to reinforce ideological and operational influences of that organization and they affected different militants in the world who joined the battlefield in Syria and Iraq or carried out terrorist attacks in the West.

Analysis of propaganda techniques reflects the following topics: liturgical speeches, official media channels, social medias and encrypted communication. Besides, the research demonstrates different audiences of ISIS communication strategy, which aims at affecting emotions and at stimulating opinions and reactions. The indoctrination concerns traditional, liturgical
\end{abstract}


speeches delivered in Arabic by ISIS leader, Abu Bakr al-Baghdadi who targets local populations in mosques. Moreover, it also reflects new technologies such as radio and TV stations, official websites or social medias that include sophisticated programs, high quality pictures, graphics and videos. However, the paper also deals with some advanced computer and Internet technologies, which enable to protect identities of jihadists who follow important conversations about ISIS objectives.

Key words: "Islamic State", communication strategy, social media

\section{STRATEGIA KOMUNIKACJ "PAŃSTWA ISLAMSKIEGO"}

\section{STRESZCZENIE}

Niniejszy artykuł dotyczy nowatorskich środków masowego przekazu wykorzystywanych przez czołowe ugrupowanie dżihadystyczne nazywane Państwem Islamskim. Odpowiednie techniki propagandowe wzmacniały zaplecze ideologiczne i operacyjne organizacji i wpływały na emocje i reakcje audytorium.

Istotnym punktem badań jest przedstawienie różnych form dyskursu, w zależności od danej grupy odbiorców sprzyjającej "Państwu Islamskiemu". Zaprezentowane analizy obejmują następujące obszary: przemówienia liturgiczne, oficjalne kanały medialne, media społecznościowe i komunikacja szyfrowana. Indoktrynacja dotyczy między innymi kazań polityczno-religijnych wygłaszanych przez przywódcę ugrupowania, Abu Bakra al-Baghdadiego. Badania dotyczą także najnowszych mass-mediów (tj. stacji radiowych i telewizyjnych, stron internetowych, mediów społecznościowych). Środki masowego przekazu wykorzystywane przez "Państwo Islamskie" uwzględniają regularne wpisy internetowe, anglojęzyczne oświadczenia, wysokiej jakości zdjęcia, grafiki i filmy adresowane do młodego pokolenia, w tym zachodnich dżihadystów, dla których tabloidyzacja przekazu stała się popularną formą komunikacji. Artykuł podejmuje również zagadnienia związane z zaawansowanymi technologiami komputerowymi i internetowymi, które pozwalają chronić tożsamość dżihadystów, którzy, obok kwestii ideologicznych, poruszają istotne kwestie programowe $\mathrm{i}$ organizacyjne.

Słowa kluczowe: "Państwo Islamskie", strategia komunikacji, media społecznościowe 